\title{
DARI TEORI KE INDIKATOR UKURAN: KAJIAN PENILAIAN PEMBENTUKAN JARINGAN PERKHIDMATAN KEBAJIKAN KANAK-KANAK
}

\author{
Siti Hajar binti Abdul Rauf ${ }^{1}$
}

\begin{abstract}
Abstrak
Most social scientists face a challenge to decide on which theory to use to explicate observable facts under investigation. Once managed to identify the theory, the next hindrance is the operationalization of the abstract hypotheses and assumptions into tangible variables. Theory operationalization is vital to the formation of the scope of the study and subsequently the research instrument. Many researchers stuck at this stage. In this regards, the researcher wants to share her experiences in dealing with this challenge, via a qualitative study that was conducted to examine the development of child welfare network services in Malaysia. The study was designed based on the Social Network Theory. Three major components of the theory that were converted to tangible variables are the form, the system and the distributions of the social network. Ways in which those variables were transformed and developed to the scope of the study and subsequently to the measurable indicators in the instrument of the study are described in this paper.
\end{abstract}

Kata kunci: Teori Jaringan Sosial, jaringan kebajikan kanak-kanak, kanak-kanak dalam jagaan institusi.

\footnotetext{
${ }^{1}$ Penulis merupakan pensyarah di Fakulti Sains Sosial Gunaan, Universiti Sultan Zainal Abidin, Terengganu dan merupakan calon Ph.D di Jabatan Pentadbiran dan Keadilan Sosial, Universiti Malaya.
}

Penulis Koresponden: Siti Hajar Abdul Rauf(hajarrauf@,unisza.edu.my) 


\section{Pendahuluan}

Memilih teori yang sesuai untuk diaplikasikan ke dalam kajian adalah satu perkara yang rumit. Ini kerana, teori bersifat abstrak dan sukar diukur. Teori dengan sendirinya tidak memberikan apa-apa makna kepada penulisan sekiranya teori berkenaan gagal dioperasionalisasikan ke serangkaian indikator yang boleh diukur. Namun begitu, dalam kajian sains sosial teori memainkan peranan yang sangat penting untuk memberi penjelasan, ramalan dan kesimpulan menyeluruh mengenai sesuatu kajian yang dilakukan (Creswell, 1998). Tetapi, bilakah teori harus dipilih dan ditentukan? Sebelum memulakan kajian, semasa ataupun setelah data-data kajian selesai dipungut?

Idea tentang kerangka teori dan kerangka konsep adalah saling berkait dengan kerangka kajian. Kerangka kajian merujuk kepada struktur idea yang abstrak atau logik yang menjadi panduan kepada perancangan, pelaksanaan dan laporan sesuatu kajian. Ia merupakan struktur yang mencantumkan bahagianbahagian dalam sesuatu kajian untuk membentuk keseluruhan kajian (Nik Azis, 2003). Menurut Ary, Jacobs dan Razavieh (1996) dan Silverman (2005), kerangka kajian adalah sangat penting dalam sebarang kajian. Kerangka kajian membekalkan landasan kepada kajian melalui penjelasan pendekatan yang digunakan dan dianggap sebagai tempat rujukan yang menyediakan konteks bagi meneliti masalah atau persoalan yang menjadi fokus kajian.

Kerangka kajian boleh berbentuk teori atau konsep. Teori atau konsep yang dijadikan sebagai kerangka kajian harus dioperasionalisasi secara komprehensif. Ini kerana, teori atau konsep yang digunakan memandu semua aspek kajian termasuk proses mengenalpasti metodologi, memilih sampel kajian, teknik pengumpulan data, teknik analisis dan cara mempersembahkan data-data kajian. Dalam artikel ini, penulis menerangkan dengan teliti cara-cara bagaimana andaian-andaian utama atau komponen-komponen utama dalam teori diubah kepada serangkaian indikatorindikator empirikal yang boleh diukur. Penulis menggunakan Teori Jaringan Sosial (Social Networking Theory) dalam kajian "Penilaian Pembentukan Jaringan Perkhidmatan Kebajikan Kanak-kanak dalam Jagaan Institusi Awam” sebagai 
contoh. Artikel ini menjelaskan secara terperinci cara bagaimana teori yang diguna pakai dapat diaplikasi dan dihubungkait dengan hasil kajian secara padu.

\section{Andaian-Andaian Teoritikal Dalam Teori Jaringan Sosial}

Dalam bidang kebajikan sosial, Teori Jaringan Sosial lazimnya digunakan untuk mengoperasionalisasi corak hubungan kerjasama dan cara kerja pihak-pihak yang terlibat di dalam penyediaan dan penyampaian perkhidmatan sosial. Kajian ini mengkaji pembentukan jaringan kebajikan kanak-kanak yang dilakukan di antara pihak institusi dengan sektor-sektor sosial yang menyediakan perkhidmatan kebajikan terhadap kanak-kanak; khususnya kanak-kanak yang berada di dalam institusi jagaan awam negara. Justeru, teori ini sangat relevan untuk menjadi kerangka atau asas analitikal bagi memahami pembentukan jaringan yang dilakukan oleh pihak institusi dengan pihak-pihak yang berkepentingan dalam menyampaikan perkhidmatan kebajikan kanak-kanak.

Teori Jaringan Sosial menerangkan mengenai keadaan pertalian dan/atau hubungan sosial yang terbina di antara manusia atau organisasi menerusi hubung kait dan kebergantungan di antara satu sama lain. Hubung kait dan kebergantungan antara individu dengan individu-individu lain akan menghasilkan satu jaringan sosial; khususnya apabila individu-individu atau organisasi-organisasi tersebut mula berhubung untuk berkongsi pendapat dan sumber, meluahkan harapan dan perasaan, meminta pertolongan, memberi nasihat serta menyampaikan maklumat melalui interaksi dua hala secara berulang-ulang atau berterusan.

Mengikut Teori Jaringan Sosial, terdapat dua perkara utama yang menjadi asas untuk membentuk dan menghasilkan satu jaringan perhubungan; iaitu objek dan ikatan. Kewujudan objek yang dihubungkan kepada objek-objek lain melalui satu ikatan secara bertimbal balik akan menghasilkan satu jaringan sosial. Oleh itu, dalam sistem kebajikan kanak-kanak, hubungan yang wujud di antara agensi dan/ atau organisasi akan menghasilkan satu jaringan perkhidmatan kebajikan kanakkanak yang komprehensif kerana setiap sektor dalam sistem perkhidmatan kebajikan kanak-kanak saling bekerjasama antara satu sama lain. Kerjasama dan 
kebergantungan antara satu sama lain diperlukan untuk memenuhi segala hak kanak-kanak yang sepatutnya dinikmati oleh mereka.

Dalam teori jaringan sosial, andaian-andaian teoritikal adalah berbentuk abstrak dan sukar diukur. Justeru, andaian-andaian teoritikal yang abstrak dan sukar diukur ditransformasikan oleh pengkaji kepada realiti sosial yang bersifat konkrit, jelas dan boleh diukur secara analisis perbandingan. Mengikut Kadushin (2012), terdapat tiga perkara asas yang mempengaruhi pembentukan jaringan sosial; iaitu bentuk jaringan, sistem jaringan sosial dan agihan jaringan sosial. Justeru, ketiga-tiga perkara asas ini diadaptasi oleh penulis dan dikembangkan sebagai skop kajian, dan seterusnya diubah kepada indikator-indikator nyata yang boleh diukur di dalam instrumen kajian.

\section{Bentuk jaringan}

Menurut Kadushin (2012) lagi, bentuk jaringan dilihat melalui dua bentuk yang utama; iaitu jaringan berbentuk tunggal dan jaringan berbentuk pelbagai. Jaringan tunggal merupakan bentuk jaringan yang wujud atau terbina apabila seseorang individu atau sesebuah agensi atau organisasi membina jaringan atau hubungan dengan individu atau agensi atau organisasi yang lain. Manakala, jaringan pelbagai pula merupakan jaringan yang wujud atau terbina di antara beberapa dan pelbagai agensi atau organisasi atau individu yang lain. Sebaliknya, Menurut Finch (1989), Finch dan Mason (1993), serta Putnam (2000), terdapat dua bentuk jaringan sosial. Pertama, jaringan sosial formal. Kedua, jaringan sosial tidak formal.

Mengaplikasi bentuk ini ke dalam sistem jaringan perkhidmatan kebajikan kanak-kanak, jaringan kebajikan kanak-kanak dapat dibahagikan kepada dua bentuk yang utama; iaitu jaringan sosial formal dan jaringan sosial tidak formal. Jaringan sosial tidak formal merujuk kepada perkhidmatan sosial, sokongan sosial dan bantuan sosial kanak-kanak oleh sektor tidak formal seperti keluarga, orang dan/atau agensi persendirian, jiran tetangga, sahabat handai dan ahli komuniti. Manakala, jaringan sosial formal merupakan hubungan yang dilakukan dengan sektor awam, sektor swasta dan sektor sukarela yang mempunyai kepakaran khusus untuk mendapatkan perkhidmatan yang ditawarkan. Kedua-dua bentuk jaringan ini adalah sangat penting bagi memenuhi keperluan asas, keperluan perkembangan dan keperluan kesempurnaan diri. 


\section{Sistem jaringan}

Sistem jaringan dalam jaringan kebajikan perkhidmatan kanak-kanak pula terdiri daripada sistem "in a box" dan sistem "out of box". Sistem "in a box" merupakan hubungan yang terjalin di dalam persekitaran yang sama dan sistem "out of box" merupakan hubungan yang terjalin di luar persekitaran yang berbeza (Kadushin, 2012).

\section{Agihan jaringan}

Agihan jaringan pula merupakan perkara asas terakhir yang mempengaruhi jaringan kebajikan perkhidmatan kanak-kanak. Agihan jaringan dibahagikan kepada empat komponen yang berbeza; iaitu objek yang terlibat, hubungan ikatan, hubungan peranan, fungsi dan tanggungjawab serta arus dan pertukaran. Objek yang terlibat merupakan hubungan sosial yang berlaku melalui satu set perhubungan. Objek ataupun dikenali sebagai nod di dalam Teori Jaringan Sosial merupakan aktor yang terdiri daripada sekumpulan individu, institusi, badan-badan atau institusi-institusi kerajaan, sektor-sektor swasta, pertubuhan bukan kerajaan (NGO), badan-badan persendirian, ahli keluarga dan semua anggota masyarakat yang terlibat dalam penyediaan dan penyampaian perkhidmatan sosial.

Bagi perhubungan sosial pula, terdapat tiga prinsip yang mendasarinya; iaitu persamaan dan keakraban, populariti dan pemusatan, serta kuat/kukuh dan longgar. Prinsip persamaan merujuk kepada persamaan daripada aspek ciri-ciri perkhidmatan yang ditawarkan oleh penyedia perkhidmatan dan disebabkan oleh faktor lokasi. Manakala, keakraban pula merujuk kepada kewujudan hubungan dan kualiti hubungan yang wujud di antara agensi dan/ individu yang lain pada suatu masa yang berlainan; iaitu saling mengenali antara satu sama lain. Populariti akan wujud apabila setiap agensi dan/ atau individu yang terlibat berhubung secara timbal balik. Keadaan ini menggambarkan bahawa agensi yang sentiasa dirujuk dan mempunyai bilangan penghubung terbanyak merupakan agensi dan/ atau individu yang menawarkan perkhidmatan terpenting dan diperlukan. Pemusatan dalam 
suatu pertalian berlaku apabila kebebasan dan ketidakbergantungan mula wujud apabila jaringan hanya dilakukan dengan pihak tertentu sahaja. Keadaan ini juga menggambarkan ketiadaan hubungan yang erat.

Jaringan yang kukuh/kuat dan longgar juga turut mempengaruhi jaringan perkhidmatan kebajikan kanak-kanak. Jaringan yang kukuh/kuat merujuk kepada hubungan yang wujud yang dinilai secara sosial. Hubungan yang wujud hanya berlaku di antara pihak yang sama di dalam suatu jaringan. Agensi yang mempunyai pertalian yang kukuh/kuat sesama mereka mampu mencapai matlamat perkhidmatan dan menyampaikan maklumat secara berkesan kepada kumpulan sasar walaupun jaringan hanya berlaku dengan pihak yang sama. Namun begitu, pertalian yang longgar pula membolehkan jaringan dibentuk dengan agensi-agensi lain yang menawarkan perkhidmatan yang sama.

Aspek hubungan peranan, fungsi dan tanggungjawab pula dilihat melalui kepadatan dan rangkaian. Kepadatan dalam agihan jaringan merujuk kepada jumlah bilangan jaringan sosial atau pertalian yang dilakukan dengan pelbagai agensi sosial. Ini bermakna, semakin banyak jaringan yang dibentuk, semakin tinggi sumber sokongan sosial yang diperolehi dan semakin efektif penyampaian perkhidmatan kebajikan kanak-kanak yang disalurkan. Manakala, rangkaian pula harus dilakukan dengan pelbagai pihak kerana penglibatan semua pihak yang berkaitan memudahkan pihak institusi menjalankan fungsi dan tanggungjawab mereka secara berkesan. Kekurangan rangkaian di dalam jaringan menyebabkan wujudnya satu keadaan yang dikenali sebagai lompang yang berstruktur (structural holes). Lompang yang berstruktur ini berlaku disebabkan wujudnya satu kelompangan di mana agensi yang sepatutnya dihubungkan di dalam suatu rangkaian perhubungan jaringan, namun tidak dihubungkan.

Perkara asas terakhir yang diterangkan melalui teori jaringan sosial adalah arus dan pertukaran. Dalam jaringan sosial, arus dan pertukaran menggambarkan jaringan yang terbentuk di antara pelbagai pihak yang boleh digambarkan melalui rajah ataupun juga dikenali sebagai sosiogram. Agensi yang terlibat saling bekerjasama antara satu sama lain secara timbal balik. Pada asasnya, jaringan melibatkan dua pihak atau dikenali sebagai dyads. Namun begitu, mengikut Teori Jaringan Sosial, jaringan yang paling ringkas mengandungi tiga pihak (triad) dan jaringan yang melebihi daripada tiga pihak pula dikenali sebagai multipleks. 


\section{Proses Transformasi Andaian-Andaian Teoritikal Yang Berbentuk Abstrak Dan Sukar Diukur (intangible) Kepada Realiti Sosial Yang Bersifat Konkrit, Jelas Dan Boleh Diukur (tangible)}

Andaian-andaian teoritikal adalah berbentuk abstrak dan sukar diukur (intangible). Justeru, untuk mengukur andaian-andaian teoritikal yang berbentuk abstrak dan sukar diukur (intangible) tersebut, andaian-andaian tersebut perlu ditransformasikan kepada realiti sosial yang bersifat konkrit, jelas dan boleh diukur (tangible). Seperti yang dijelaskan dalam bahagian andaian teoritikal di atas, penulis telah memperincikan kajian "Penilaian Pembentukan Jaringan Perkhidmatan Kebajikan Kanak-kanak dalam Jagaan Institusi Awam” kepada tiga perkara asas yang terdapat dalam jaringan sosial; iaitu bentuk jaringan, sistem jaringan dan agihan jaringan.

Ketiga-tiga perkara asas tersebut dikembangkan sebagai skop kajian dan seterusnya diubah kepada indikator-indikator nyata yang boleh diukur di dalam instrumen kajian. Analisis dokumen dilakukan secara perbandingan melalui sorotan literatur ke atas kajian-kajian lepas serta berdasarkan contoh-contoh soal selidik yang digunakan oleh pengkaji-pengkaji sebelum ini. Setiap perincian berkenaan proses transformasi andaian-andaian teoritikal yang berbentuk abstrak dan sukar diukur (intangible) kepada realiti sosial yang bersifat konkrit, jelas dan boleh diukur (tangible) dijelaskan oleh pengkaji secara terperinci dalam bahagian yang seterusnya.

\section{Transformasi bentuk jaringan kepada indikator boleh ukur}

Berdasarkan kajian-kajian lepas, Finch (1989) menjelaskan bahawa jaringan tunggal berlaku di antara dan/ di dalam sesebuah isi rumah. Setiap ahli di dalam sebuah isi rumah bekerjasama dan saling melengkapi di antara satu sama lain dengan cara yang berbeza untuk meluaskan lagi agihan jaringan sehingga ke keluarga kembangan. Manakala, Coleman (1988) pula melihat jaringan tunggal merupakan hubungan yang berlaku di antara anak dan ibu bapa (parents-child relations). Berbeza pula dengan Stone (2001) yang melihat bentuk jaringan secara tunggal berlaku di dalam suatu proses untuk menyelesaikan sesuatu isu ataupun dalam keadaan untuk 
menyelesaikan sesuatu masalah. Contohnya, untuk mencari pengasuh kepada seorang bayi, ataupun untuk mencari sekolah, ataupun untuk mendapatkan nasihat mengenai kewangan dan juga untuk mendapatkan sesuatu perkhidmatan yang sama atau hampir sama. Justeru, seseorang individu akan menyelesaikan masalah yang dihadapi dengan mencari suatu alternatif sehingga masalah yang dihadapi dapat diselesaikan. Begitu juga dengan Dudwick et al., (2006) yang melihat jaringan tunggal yang berlaku di antara kumpulan yang signifikan; contohnya disebabkan gender, bahasa, agama, kumpulan etnik dan juga mungkin disebabkan oleh persamaan status sosial.

Seterusnya, Finch (1989) mendapati bentuk jaringan yang pelbagai boleh berlaku secara tidak formal apabila sesebuah komuniti mempunyai minat dan kepentingan yang sama dan mempunyai ikatan di antara satu sama lain. Contohnya, pertalian yang wujud di antara ahli keluarga, saudara mara, serta hubungan akrab yang wujud dalam kalangan kejiranan. Manakala, Kadushin (2012) pula melihat jaringan daripada pelbagai pihak dapat membantu mengatasi kekangan yang dihadapi oleh sesebuah organisasi dalam mendapatkan perkhidmatan yang diperlukan. Kekangan berkenaan berlaku mungkin disebabkan oleh masa, kurang kepercayaan dan juga keupayaan untuk melakukan sesuatu. Justeru, sokongan dan kerjasama daripada pihak luar amat diperlukan untuk mengarasi masalah yang dihadapi oleh sesebuah agensi atau organisasi. Disebabkan itu, Putnam (2000) melihat jaringan dan kerjasama dengan golongan professional yang terdiri daripada pelbagai sektor kebajikan sama ada penjagaan kesihatan, perkhidmatan sosial dan juga sekolah amat diperlukan.

Berdasarkan kajian-kajian lepas dan juga contoh-contoh soalan yang dirujuk seperti daripada kajian Kadushin (2012), Dudwich et al., (2006), Stone (2001), Putnam (2000), Finch (1989), dan Coleman (1988), pengkaji telah mengubah dan mentransformasikan maklumat-maklumat yang diperolehi daripada kajian-kajian lepas kepada indikator yang nyata berkaitan bentuk jaringan. Indikator-indikator yang dibina diaplikasikan mengikut kesesuaian kajian pengkaji; iaitu berkaitan pembentukan jaringan perkhidmatan kebajikan kanak-kanak yang dilakukan oleh pihak institusi. Soalan-soalan yang dibina untuk mengukur bentuk jaringan perkhidmatan kebajikan kanak-kanak adalah seperti di bawah : 
i. Agensi manakah yang terlibat dalam menyedia dan memastikan keperluan asas (makanan dan minuman, kemudahan tempat tinggal yang selesa, pakaian dan keperluan-keperluan lain, kesihatan) serta insurans (insurans nyawa dan insurans sosial kanak-kanak di sini mencukupi?

ii. Mengapakah mereka terlibat?

iii. Apakah peranan atau tanggungjawab mereka terhadap kanak-kanak di sini? iv. Apakah masalah/halangan yang dihadapi dalam menjalani tanggungjawab ini?

\section{Transformasi sistem jaringan kepada indikator boleh ukur}

Menurut Kadushin (2012), sistem "in a box" juga dikenali sebagai jaringan tertutup. Jaringan yang berlaku di antara aktor-aktor merupakan jaringan yang berlaku di dalam satu persekitaran yang sama iaitu sama ada dalam kelas yang sama, kawasan yang sama ataupun dalam komuniti yang sama tanpa melibatkan kelas, kawasan dan juga komuniti yang lain. Menurut Stone (2001), terdapat beberapa soalan yang boleh diajukan kepada seseorang atau sesebuah agensi untuk menggambarkan individu atau agensi berkenaan dikategorikan dalam jaringan yang tertutup. Contohnya, adakah anda merupakan sebahagian daripada kumpulan kerja ini?, Adakah rakan sekerja anda juga merupakan jiran ataupun rakan anda? Di antara jiran-jiran anda, yang manakah antara mereka yang anda kenali secara personal?. Namun, Coleman (1988) pula berpendapat, darjah yang menentukan sesuatu jaringan sama ada tertutup atau terbuka diambilkira melalui implikasi kualiti hubungan yang wujud dan juga terhadap output yang dihasilkan secara produktif.

Setelah membuat perbandingan di antara literatur-literatur kajian, pengkaji telah mengubah dan mentransformasikan maklumat-maklumat yang diperolehi daripada kajian-kajian lepas kepada indikator yang nyata berkaitan sistem jaringan. Indikator-indikator berkenaan diaplikasikan mengikut kesesuaian kajian dan soalan-soalan yang dibina untuk mengukur sistem jaringan perkhidmatan kebajikan kanak-kanak adalah seperti di bawah :

i. Adakah agensi X yang dinyatakan tadi adalah dari kumpulan organisasi daripada JKMM? 
ii. Selain agensi yang dinyatakan tadi (agensi daripada kumpulan JKMM), adakah masih terdapat agensi-agensi atau individu-individu lain daripada luar yang turut terlibat dalam penyampaian perkhidmatan ini?

iii. Mengapakah agensi dan individu daripada luar kumpulan JKMM turut dilibatkan?

iv. Apakah faktor dan matlamat utama pembentukan jaringan/kerjasama ini dengan pihak luar dilakukan?

v. Apakah masalah/halangan yang seringkali dihadapi apabila melakukan jaringan/kerjasama dengan pihak-pihak luar?

\section{Transformasi agihan jaringan kepada indikator boleh ukur}

Seterusnya, Teori Jaringan Sosial juga menerangkan mengenai agihan jaringan sosial; iaitu cara bagaimana sesebuah organisasi atau sekumpulan individu berkongsi sesuatu sumber sesama mereka. Dengan kata lain, agihan menggambarkan penyebaran sesuatu perkara (spt. perkhidmatan, sumber, idea) di dalam sesebuah kawasan, ruangan fizikal dan ruang masa tertentu (Kadushin, 2012). Pertalian yang wujud atau berlaku di antara nod-nod yang mewakili individu atau organisasi melambangkan perhubungan dan pergantungan yang wujud antara satu sama lain (Kadushin, 2012; Streeter \& Gillespie, 1992). Sepertimana yang digambarkan secara grafik menerusi Rajah 1 di bawah, perhubungan ikatan jaringan perkhidmatan bagi nod-nod yang pelbagai ini dilambangkan oleh garis lurus yang menghubungkan antara satu nod dengan nod-nod yang lain.

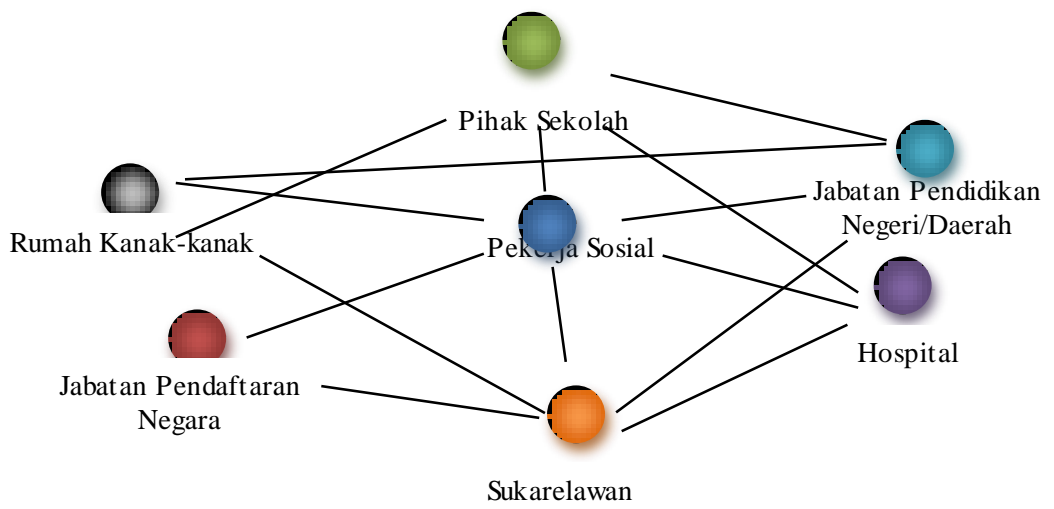

Rajah 1: Penghubung di antara nod-nod 
Bagi kanak-kanak yang ditempatkan di institusi jagaan awam negara, pihak institusi yang terdiri daripada pegawai JKM bertindak sebagai penghubung untuk menjalinkan hubungan dengan agensi-agensi sosial lain bagi memenuhi keperluan kanak-kanak secara komprehensif. Selain sumber manusia yang mengendali perkhidmatan, undang-undang atau dasar sosial juga boleh menjadi penghubung ikatan jaringan perkhidmatan. Contohnya, bagi konteks kanak-kanak yang berada di dalam jagaan institusi, kebajikan mereka telah digazetkan oleh Akta Kanak-kanak 2001, Konvensyen Mengenai Hak Kanak-kanak dan Dasar Perlindungan Kanakkanak Negara. Mana-mana agensi yang "dilantik” dan disenaraikan oleh legislatif dan dasar sosial berkenaan perlu berhubungan bagi membentuk satu jaringan sosial perkhidmatan kebajikan kanak-kanak. Pertalian yang wujud antara penghubung ikatan jaringan lazimnya dibina atau terbina berasaskan kepada empat prinsip yang segandingan; iaitu persamaan (homophily) dan keakraban (propinquity) serta kepopularan (popularity) dan pemusatan (centrality) (Kadushin, 2012).

\section{Persamaan dan keakraban}

Prinsip persamaan merujuk kepada persamaan yang wujud; iaitu persamaan dari segi ciri-ciri perkhidmatan yang ditawarkan oleh penyedia perkhidmatan dengan perkhidmatan yang diperlukan oleh kanak-kanak. Selain itu, prinsip persamaan juga dipengaruhi oleh faktor lokasi. Manakala, prinsip keakraban pula merujuk kepada kewujudan hubungan dan kualiti hubungan yang wujud di antara individu/agensi dengan individu/agensi lain pada suatu masa yang berlainan. Oleh itu, disebabkan wujudnya ciri-ciri persamaan, berada di satu lokasi yang berdekatan serta pernah mengenali dan mempunyai pertalian dengan pihak penyedia perkhidmatan kebajikan kanak-kanak sebelum ini, maka agensi yang "dilantik" akan menjalinkan jaringan sosial dengan pihak berkenaan bagi memenuhi keperluan yang diperlukan.

Contohnya, untuk mendapatkan perkhidmatan kesihatan, pihak institusi akan menjalinkan pertalian dengan Kementerian Kesihatan. Justeru, pihak-pihak yang terlibat adalah pihak hospital, klinik swasta, klinik persendirian, doktor, pembantu perubatan, jururawat, pekerja sosial dan juga sukarelawan yang mungkin pernah dikenali oleh pihak institusi. Kedudukan lokasi yang berdekatan dengan institusi kebajikan kanak-kanak berkenaan mendorong mereka untuk menjalinkan jaringan sosial perhubungan kerana mereka menawarkan 
perkhidmatan yang sama dan berkaitan. Semua agensi tersebut menawarkan perkhidmatan yang sama; iaitu perkhidmatan kesihatan. Pengaruh dan kebergantungan yang wujud di antara agensi-agensi yang berhubungan menyebabkan wujudnya pertalian secara timbal balik antara satu sama lain.

Konsep asas Teori Jaringan Sosial ini telah dioperasionalisasi oleh pengkaji supaya konsep persamaan dan keakraban dapat diukur di dalam kajian yang dijalankan. Antara soalan-soalan yang dibina untuk mengukur kedua-dua prinsip ini adalah seperti berikut:

i. Apakah perkara yang menjadi panduan kerjasama antara agensi-agensi yang terlibat?

ii. Adakah jaringan/kerjasama yang dilakukan dengan agensi X disebabkan oleh kedudukan agensi X yang berada berdekatan dengan institusi ini?

iii. Adakah kerjasama/jaringan yang dilakukan disebabkan agensi mempunyai interes dan tujuan yang sama dengan agensi ini?

iv. Adakah jaringan yang wujud disebabkan terikat dengan sumber atau fasiliti yang sama?

v. Adakah agensi-agensi ini mempunyai hubungan yang baik antara satu sama lain?

vi. Sekiranya terdapat sebarang masalah, adakah agensi yang terlibat turut membantu agensi lain?

\section{Populariti vs pemusatan}

Populariti dan pemusatan (centrality) juga merupakan antara faktor yang diambilkira untuk melihat pembentukan jaringan kebajikan kanak-kanak. Perkhidmatan kebajikan yang disediakan menggambarkan populariti apabila agensi yang terlibat di dalam perkhidmatan kesihatan saling berhubung secara timbal balik. Bilangan penghubung yang terbanyak menggambarkan agensi atau organisasi yang menawarkan perkhidmatan yang penting dan amat diperlukan; iaitu dengan syarat secara timbal balik (Kadushin, 2012).

Mengikut Teori Jaringan Sosial, sekiranya institusi tidak memperlihatkan hubungan dengan agensi-agensi lain atau hanya menjalinkan pertalian jaringan dengan pihak tertentu sahaja untuk mendapatkan perkhidmatan kebajikan yang diperlukan oleh kanak-kanak, kebebasan dan ketidakbergantungan mula wujud. Keadaan ini menggambarkan ketidakwujudan hubungan yang erat antara institusi 
kebajikan kanak-kanak dengan semua pihak yang menawarkan perkhidmatan kebajikan. Menurut Leavitt (1950), kewujudan pemusatan akan mengakibatkan wujudnya defisit ke atas perkhidmatan yang diterima oleh klien perkhidmatan kerana hanya kanak-kanak tertentu sahaja dapat menikmati perkhidmatan yang ditawarkan dengan kepuasan yang tinggi.

Setelah prinsip ini dioperasionalisasi, pengkaji mengukur prinsip ini dengan soalan-soalan yang berikut:

i. Adakah hubungan/kerjasama yang dijalinkan dengan agensi-agensi dan individu-individu yang terlibat adalah bersifat sehala?

ii. Antara agensi-agensi ini, agensi manakah yang paling signifikan dalam urusan memastikan kanak-kanak di sini diberi kemudahan yang sewajarnya?

iii. Adakah agensi ini boleh membuat keputusan sendiri untuk melakukan kerjasama dengan agensi lain yang berkaitan sekiranya memerlukan perkhidmatan tambahan?

iv. Sekiranya terdapat kes-kes kecemasan atau perkara-perkara yang memerlukan tindakan segera, agensi manakah yang dirujuk terlebih dahulu?

\section{Kuat/kukuh dan longgar}

Seterusnya, jarak (distance) hubungan yang wujud juga boleh mempengaruhi prinsip persamaan dan keakraban. Jarak hubungan juga boleh dinilai secara sosial; iaitu kualiti keakraban hubungan. Jaringan sosial yang kukuh/kuat merujuk kepada agensi-agensi yang mempunyai pertalian yang kuat/kukuh di antara sesama mereka. Jaringan sosial sebegini selalunya mampu mencapai matlamat perkhidmatan dan mampu menyampaikan perkhidmatan kepada kumpulan sasar secara berkesan. Walaupun jaringan sosial yang lemah sering dikritik kerana kegagalannya menyediakan perkhidmatan yang komprehensif kepada klien perkhidmatan, pertalian yang longgar (weak ties) di antara pihak institusi dengan agensi-agensi sosial lain yang menawarkan perkhidmatan membolehkan pihak institusi menjalinkan jaringan perhubungan dengan agensi-agensi lain yang menawarkan perkhidmatan yang setara.

Di dalam konteks perkhidmatan kesihatan untuk kanak-kanak yang berada di dalam jagaan institusi contohnya, STB Marang juga boleh membina jaringan 
perkhidmatan kesihatan dengan klinik persendirian ataupun doktor-doktor yang bersedia untuk berkhidmat secara sukarela untuk memberi rawatan kepada kanakkanak yang memerlukan rawatan perubatan. Seandainya institusi yang didiami organisasi kanak-kanak berkenaan mempunyai hubungan yang kuat; contohnya jaringan hubungan telah ditetapkan kepada institusi untuk mendapatkan perkhidmatan kebajikan kesihatan dengan hospital kerajaan sahaja; ini menyebabkan jaringan perkhidmatan kebajikan dengan klinik swasta mahupun persendirian tidak dapat dilakukan. Jaringan perkhidmatan yang berlaku dalam suasana dan keadaan yang terhad menyebabkan hanya sebilangan kecil defisit keperluan perkhidmatan kesihatan yang dialami oleh kanak-kanak dapat dipenuhi.

Jarak hubungan yang terjalin sama ada kukuh/kuat ataupun longgar diukur dengan mengemukakan soalan-soalan berikut:

i. Adakah agensi ini mempunyai hubungan yang erat dengan agensi X?

ii. Sekiranya terdapat sebarang masalah, adakah agensi ini akan berbincang masalah yang dialami dengan agensi $\mathrm{X}$ bagi mengatasinya?

iii. Adakah agensi ini mempunyai kebebasan untuk menjalinkan kerjasama dengan agensi lain yang menawarkan perkhidmatan yang sama sekiranya agensi $\mathrm{X}$ juga tidak dapat membantu menyelesaikan masalah yang dialami?

\section{Kepadatan vs rangkaian}

Pihak institusi memainkan peranan penting dan bertanggungjawab untuk menjaga kebajikan kanak-kanak dan memenuhi segala hak mereka secara komprehensif. Jaringan perhubungan harus dilakukan dengan pelbagai pihak. Dalam Teori Jaringan Sosial, jumlah bilangan jaringan sosial atau pertalian yang dilakukan dengan pelbagai agensi sosial untuk mendapatkan perkhidmatan bagi memenuhi hak kehidupan, hak perkembangan, hak perlindungan dan hak penyertaan kanakkanak yang ditempatkan di institusi jagaan awam dikenali sebagai kepadatan (density) jaringan (Kadushin, 2012). Semakin banyak jaringan yang dibentuk oleh pihak institusi, semakin tinggi sumber sokongan sosial yang diperolehi dan semakin efektif penyampaian perkhidmatan kebajikan yang dapat disalurkan kepada semua kanak-kanak yang berada ditempatkan di institusi berkenaan (Thompson \& Peebles-Wilkins, 1992). 
Contohnya, seseorang kanak-kanak memerlukan pendidikan untuk perkembangan kehidupan mereka sepertimana kanak-kanak yang berada di luar institusi. Justeru, pihak institusi berperanan untuk menjalinkan hubungan dengan pihak Kementerian Pelajaran, Pejabat Pendidikan Negeri/Daerah, pihak sekolah, PIBG, guru kelas, Jabatan Pendaftaran Negara, sukarelawan, pekerja sosial, masyarakat setempat dan mungkin guru-guru yang bersara tetapi sanggup menawarkan perkhidmatan pendidikan secara sukarela sama ada berbentuk tuisyen di luar institusi mahupun ke institusi berkenaan untuk membantu kanak-kanak yang memerlukan. Penglibatan semua pihak yang berkaitan memudahkan segala urusan dan membolehkan pihak institusi menjalan fungsi dan tanggungjawab mereka secara kondusif dan berkesan.

Kekurangan rangkaian dalam jaringan untuk memenuhi keperluan pendidikan kanak-kanak akan menyebabkan wujudnya "lompang yang berstruktur" (structural holes). Lompang yang berstruktur merupakan ketiadaan atau ketidakwujudan jaringan perhubungan yang sepatutnya dilakukan di antara setiap ahli/agensi yang terlibat. Ahli/agensi yang terlibat perlu dihubungkan dan dipadankan dengan betul di antara satu sama lain secara berstruktur. Namun, ketiadaan pautan antara salah satu ahli/agensi yang terlibat dalam satu pertalian akan mewujudkan "lompang yang berstruktur" (Kadushin, 2012).

Contohnya, kanak-kanak yang berada di institusi perlu ke sekolah dan menjalani rutin harian seperti kanak-kanak yang lain. Namun, ketiadaan dokumen pengenalan diri yang mungkin dialami oleh mereka sebelum mereka ditempatkan di sesebuah institusi menyukarkan mereka untuk mendapatkan perkhidmatan pendidikan yang sepatutnya dinikmati. Justeru, menjadi tanggungjawab pihak institusi untuk menyelesaikan masalah yang dialami dengan mengambil langkah yang bijak untuk menjalinkan jaringan sosial dengan Jabatan Pendaftaran Negara untuk mendapatkan dokumen yang mungkin bersifat sementara untuk suatu tempoh masa tertentu bagi membolehkan kanak-kanak berkenaan dapat meneruskan persekolahan sebelum mendapat dokumen pengenalan diri yang sebenar. Kelompangan yang wujud akan menyebabkan berlakunya satu keadaan yang dikenali sebagai "lompang yang berstruktur" di dalam Teori Jaringan Sosial. 
Proses operasionalisasi kepadatan dan rangkaian dilakukan dengan mengemukakan soalan-soalan berikut:

i. Berapa banyakkah agensi yang terlibat dalam menyediakan kemudahan untuk kehidupan untuk kanak-kanak di sini?

ii. Adakah kerjasama yang dijalinkan dengan agensi X memudahkan pihak STB mencapai matlamat untuk menyedia dan memenuhi semua keperluan kehidupan kanak-kanak di sini?

iii. Apakah masalah yang dihadapi oleh agensi ini dalam menjalankan fungsi dan tanggungjawab secara berkesan di institusi ini?

iv. Apakah punca/penyebab utama berlakunya masalah ini?

v. Siapakah yang sepatutnya bertanggungjawab untuk mengatasi masalah yang dihadapi ini?

\section{Penutup}

Teori dan penyelidikan saling berhubungan antara satu sama lain. Disebabkan itu, teori memainkan peranan yang sangat penting dalam suatu kajian. Teori yang dioperasionalisasi dengan jelas dan nyata memudahkan sesebuah kajian dijalankan dan dikembangkan. Dalam kajian ini, teori merupakan titik awal dan titik akhir proses penyelidikan. Dengan kata lain, teori yang digunakan dan dioperasionalisasi merupakan kaca mata yang digunakan oleh pengkaji untuk meneliti fenomena pembentukan jaringan kebajikan dalam kajian ini. Kegunaan teori dalam kajian ini bukan hanya terhad kepada penjelasan apa yang sedang berlaku, tetapi juga membantu pengkaji meramalkan apa yang akan dan sepatutnya dilakukan dalam proses menjalankan penyelidikan. Namun begitu, keperluan untuk mengembangkan teori atau dengan kata lain mengoperasionalisasikan teori daripada yang bersifat abstrak kepada yang berifat nyata dan konkrit merupakan satu cabaran yang mencabar kepada mana-mana pengkaji dan ia harus dilakukan secara berterusan. 


\section{Rujukan}

Ary, D., Jacobs, L. C., \& Razaveih, A. (1996). Introduction to Research in Education (15th ed.). New York: Harcourt Brace.

Creswell, J. W. (1998). Qualitative Inquiry and Research Design: Choosing Among Five Traditions. Thousand Oaks: SAGE Publications.

Dudwick, N., Kuehnast, K., Jones, V. N., \& Woolcock, M. (2006). Analyzing Social Capital in Context: A Guide to Using Qualitative Methods and Data. Washington, D.C.: World Bank Institute.

Finch, J. (1989). Family Obligations and Social Change. Cambridge: Polity Press.

Finch, J. and Mason, J. (1993). Negotiating Family Responsibilities. London: Tavistock Routledge.

Kadushin, C. (2012). Understanding social networks: Theories, concepts, and findings. New York: Oxford University Press.

Nik Azis Nik Pa. (2003). Penggunaan Teori dan Kerangka Teori dalam Penyelidikan Pendidikan Matematik. Masalah Pendidikan, 26, 29-61.

Putnam, R. D. (2000). Bowling Alone. New York: Simon \& Schuster Paperbacks.

Silverman, D. (2005). Doing Qualitative Research: A Practical Handbook (2nd ed.). London: SAGE Publications Ltd.

Stone, W. (2001). Measuring Social Capital: Towards a Theoritically Informed Measurement Framework for Reaching Social Capital in Family and Community Life. http://www.aifs.gov.au/institute/pubs/RP24.pdf

Streeter, C. L., \& Gillespie, D. F. (1992). Social Network Analysis. Journal of Social Service Research, 16(1/2), 201-222.

Thompson, M. S., \& Peebles-Wilkins, W. (1992). The impact of Formal, Informal and Societal Support Networks on the Psychological Well-being of Black Adolescent Mothers. Social Work, 37(4), 322-328. 